\title{
Acute Coronary Syndrome Developed after Vincristine Administration
}

\author{
Vinkristin Tedavisi Sonrası Gelişen Akut Koroner Sendrom
}

\author{
Serkan ÖZTÜRK, ' Davut BALTACI, ${ }^{2}$ Selim AYHAN, ${ }^{1}$ Mehmet YAZICI, ${ }^{1}$ Ayhan SARITAŞ ${ }^{3}$ \\ 'Department of Cardiology, Abant Izzet Baysal University, Faculty of Medicine, Bolu, Turkey; \\ Departments of ${ }^{2}$ Family Medicine, ${ }^{3}$ Emergency Department, Duzce University Faculty of Medicine, Düzce, Turkey
}

\begin{abstract}
SUMMARY
Vincristine and doxorubicin are among the most effective chemotherapeutic agents used in the treatment of malignancies in combination per protocols. However, these chemotherapeutic agents possess great risk for development of cardiotoxicity. The most common manifestations of cardiotoxicity due to use of those chemotherapeutic agents are arrhythmias, systolic dysfunction, cardiomyopathy, pericardial injury and myocardial ischemia. We present a case of acute coronary syndrome with complete atrio-ventricular (AV) block, developed after vincristine and doxorubicin chemotherapy in a patient with multiple myeloma and no cardiac history.
\end{abstract}

Key words: Atrio-ventricular block; doxorubicin; myocardial infarction; vincristine.

\section{Introduction}

Vincristine and doxorubicin in combination are widely used as chemotherapeutic agents as part of the vincristine-adriamycin-dexamethasone (VAD) protocol. However, they have several side effects. Cardiac toxicity of vincristine and doxorubicin are affected by age, gender, pre-existing heart disease, hypertension and mediastinal irradiation. ${ }^{[1]}$ Cardiac toxicity may occur both in early and late stages after administration of vincristine. ${ }^{[2]}$ The most commonly seen manifestations are arrhythmias, myocardial dysfunction, pericardial injury and myocardial ischemia. ${ }^{[1,3]}$ Acute coronary syndrome has been reported as an uncommon, but serious, complication of treatment with vincristine. ${ }^{[4,5]}$

\section{ÖZET}

Vinkristin ve doksorubisin kombinasyonu kemoterapi protokolü olarak malignitelerin tedavisinde kullanılan en etkili kemoterapötik ajanlardandır. Ancak, bu kemoterapötik ajanlar kardiyotoksisite gelişimi için oldukça risklidir. Bu kemoterapötik ajanlar nedeniyle en sık görülen toksik yan etkiler, aritmiler, sistolik disfonksiyon, kardiyomiyopati, perikardiyal yaralanma ve miyokard iskemisidir. Burada, kardiyak açıdan risk faktörü olmayan multipl myelom tanısı ile vinkristin ve doksorubisin kemoterapisi aldıktan sonra akut koroner sendrom ve atriyoventriküler (AV) blok gelişen bir olguyu sunuyoruz.

Anahtar sözcükler: Atriyoventriküler blok; doksorubisin; miyokardiyal infarktüs; vinkristin. 


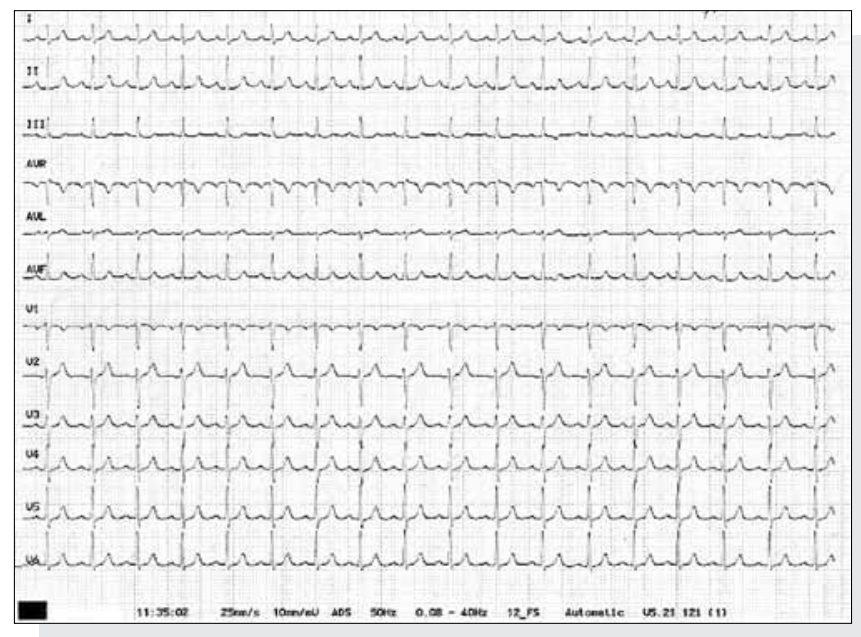

Figure 1. Electrocardiogram before chemotherapy.

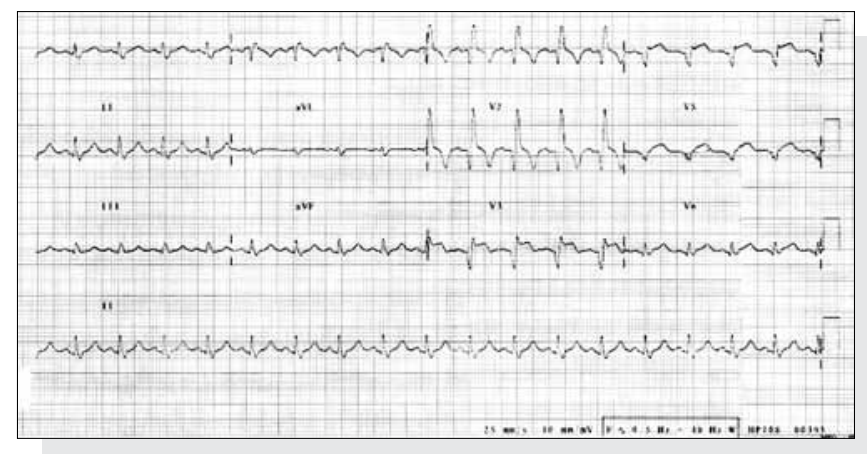

Figure 2. Electrocardiogram shows ST elevation and incomplete RBBB in emergency service.

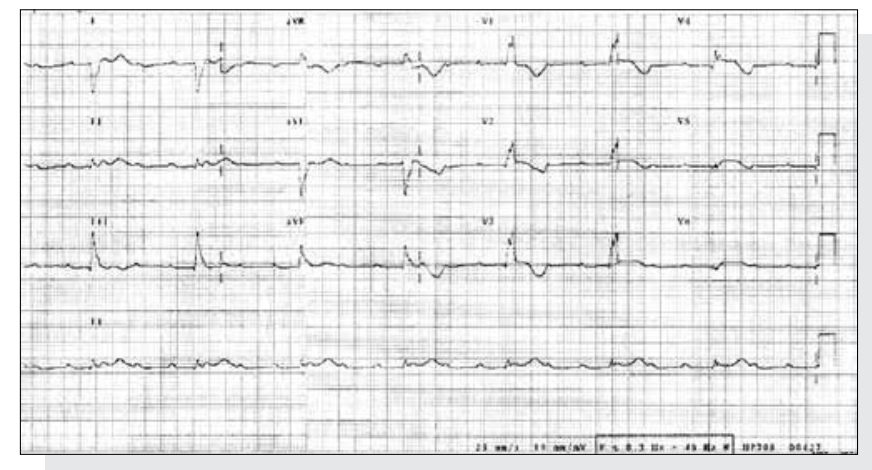

Figure 3. Electrocardiogram shows complete AV block in coronary care units.

cigarette smoking, family history) except age. On cardiac examination, she was physically normal. Electrocardiography showed sinus tachycardia with a heart rate of 103 beats per minute (bpm) (Figure 1). Echocardiography revealed normal cardiac dimensions and normal systolic function. On the basis of these findings, the patient was evaluated as fit to re- ceive chemotherapy treatment. Following the 4 th course of VAD chemotherapy protocol was given, she was discharged from the clinic.

The patient began to experience typical anginal chest pain in the second day of discharge. She was admitted to the emergency department on the 18th hour of beginning of chest pain. ST elevation in V1 through V6, incomplete right bundle branch block (RBBB), and sinus tachycardia were observed on ECG recording of the patient while in the emergency department (Figure 2). The patient was immediately diagnosed with acute anterior myocardial infarction, and was transferred to the coronary intensive care unit. Signs of complete AV block developed on ECG few hours after the admittance (Figure 3). A transient pacemaker was implanted to the patient due to hypotension. Cardiac markers obtained with the following results: troponin $=6.70 \mathrm{ng} / \mathrm{ml}$, creatine kinase $(C K)=3061 \mathrm{U} / \mathrm{L}$, creatine kinase muscle-brain type $(\mathrm{CKMB})=468 \mathrm{U} / \mathrm{L}$ and $\mathrm{CKMB}$ protein $=408 \mathrm{ng} / \mathrm{ml}$. Hemogram and other biochemical markers of the patient were normal. The patient's rhythm improved after 1 week followup. Segmental wall motion disorder and apico-septal aneurysm consistent with anterior myocardial infarction was observed, and the ejection fraction was evaluated as $30 \%$ on echocardiography. There was no significant lesion on coronary angiography, except a plaque formation in the mid portion of the left anterior descending artery. The patient was discharged from the hospital on the 6th day of admission, with recommended treatment with ramipril $2.5 \mathrm{mg} / \mathrm{d}$, metoprolol $50 \mathrm{mg} / \mathrm{d}$, atorvastatin $40 \mathrm{mg} / \mathrm{d}$, acetylsalicylic acid $100 \mathrm{mg} / \mathrm{d}$. During the follow-up one month later, the patient underwent control echocardiography. Echocardiography revealed apico-septal aneurysm and improved left ventricular function (ejection fraction 50\%).

\section{Discussion}

Vincristine and doxorubicin are widely used in the treatment of oncologic diseases, and they both possess cardiotoxic effects. It has been shown in the literature that vinca alkaloids, such as vincristine, cause endothelial damage and myocardial ischemia ${ }^{[6,7]}$ It has also been demonstrated that cardiotoxic effects of doxorubicin are associated with excessive free radical formation and decrease in antioxidant radicals, sarkolemmal sodium-calcium exchange deterioration, and disruption of energy metabolism in myocardial cells. ${ }^{[2,8]}$ Doxorubicin has been responsible for cardiomyopathy, especially dilated cardiomyopathy, and its cardiotoxic affects are attenuated by vincristine. Combination of doxorubicin with vincristine is associated with a significant decrease in cytochrome $C$ release, suggesting reduction of oxidative stress and inhibition of mitochondrial permeability transition. ${ }^{[9]}$ 
Chest pain, T-wave inversions on ECG without rising of cardiac enzymes and symptoms of reversible cardiac ischemia as well as complicated myocardial infarction have been attributed to vinca alkaloids. ${ }^{[6]}$ Similarly, typical anginal chest pain and elevation of cardiac enzymes have occurred after vincristine is given in our case. In at least two cases of complete myocardial infarction, coronary angiography revealed normal epicardial vessels in the literature. ${ }^{[10]}$ Calvo-Romero et al. ${ }^{[5]}$ reported one patient who developed a Q-wave inferior and right ventricle myocardial infarction with post-infarction angina after receiving a third course of vincristine and doxorubicin for immunoglobulin $\mathrm{A}(\lg \mathrm{A})$ multiple myeloma. Vincristine-doxorubicin combination was administered on forth course of VAD protocol to our patient who suffered from IgA multiple myeloma. Ischemic heart disease may be serious but uncommon complication of treatment with several chemotherapeutic agents.

Herein, we presented a case with acute anterior myocardial infarction developed complete AV block after vincristine and doxorubicin therapy. It is likely that vincristine played a role in the development of anterior myocardial infarction in our patient, in the light of reports presenting similar cases in literature.

\section{Conclusion}

Vincristine is a cardiotoxic agent that it can cause ischemic heart disease. We suggest that vincristine should be used with great caution, even in patients with no preexisting cardiovascular risk factors, and physicians should be aware of this serious complication of chemotherapy.

\section{References}

1. Shan K, Lincoff AM, Young JB. Anthracycline-induced cardiotoxicity. Ann Intern Med 1996;125:47-58.

2. Steinberg JS, Cohen AJ, Wasserman AG, Cohen P, Ross AM. Acute arrhythmogenicity of doxorubicin administration. Cancer 1987;60:1213-8.

3. Jones RL, Swanton C, Ewer MS. Anthracycline cardiotoxicity. Expert Opin Drug Saf 2006;5:791-809.

4. Samuels BL, Vogelzang NJ, Kennedy BJ. Severe vascular toxicity associated with vinblastine, bleomycin, and cisplatin chemotherapy. Cancer Chemother Pharmacol 1987;19:253-6.

5. Calvo-Romero JM, Fernández-Soria-Pantoja R, Arrebola-Garcia JD, Gil-Cubero M. Ischemic heart disease associated with vincristine and doxorubicin chemotherapy. Ann Pharmacother 2001;35:1403-5.

6. Cargill RI, Boyter AC, Lipworth BJ. Reversible myocardial ischaemia following vincristine containing chemotherapy. Respir Med 1994;88:709-10.

7. Mikaelian I, Buness A, de Vera-Mudry MC, Kanwal C, Coluccio $D$, Rasmussen $E$, et al. Primary endothelial damage is the mechanism of cardiotoxicity of tubulin-binding drugs. Toxicol Sci 2010;117:144-51.

8. Lenaz L, Page JA. Cardiotoxicity of adriamycin and related anthracyclines. Cancer Treat Rev 1976;3:111-20.

9. Chatterjee K, Zhang J, Tao R, Honbo N, Karliner JS. Vincristine attenuates doxorubicin cardiotoxicity. Biochem Biophys Res Commun 2008;373:555-60.

10. Allal J, Becq-Giraudon B, Pouget-Abadie JF, Sudre Y, Barraine R. 2 new cases of myocardial infarction after injection of vincristine. [Article in French] Ann Cardiol Angeiol (Paris) 1984;33:469-70. 